\title{
Measurement of urea and ammonium concentrations in gastric juice
}

\author{
W D Neithercut, A M El Nujumi, K E L McColl
}

\begin{abstract}
Aim-To study the effect of known interference in the measurement of urea and ammonium concentrations in samples of gastric juice.

Method-The effect of pH and ammonium concentration on the o-pthalaldehyde method, the diacetylmonoxime method, a Berthelot linked method and an enzymatic urease method for the measurement of urea in gastric juice was therefore conducted. An enzymatic method of the measurement of ammonium in gastric juice was also assessed. Results-The o-pthalaldehyde and the enzymatic urease methods were unaffected by a low gastric juice pH, ammonium concentrations of $10 \mathrm{mmol} / \mathrm{l}$, and had interassay coefficients of variation of $3 \cdot 9-5 \cdot 6 \%$ and $2 \cdot 8-10 \cdot 6 \%$, respectively, over a urea concentration of $2.5 \mathrm{mmol} / 1-$ $20 \mathrm{mmol} / \mathrm{l}$. The Berthelot linked method resulted in low gastric juice urea concentrations. The enzymatic method of ammonium measurement also proved suitable when the effect of low gastric juice pH was controlled.

Conclusion-Interference by low pH did not explain the differences in reports of gastric juice urea or ammonium concentrations.
\end{abstract}

(F Clin Pathol 1993;46:462-464)

There is a clear association between the development of duodenal ulcer disease and infection of the gastric antral mucosa by Helicobacter pylori. ${ }^{12}$ This micro-organism has abundant urease activity which enables it to hydrolyse gastric juice urea with the production of ammonium and carbon dioxide. ${ }^{34}$ Its urease activity has been used to detect the presence of infection by the ${ }^{14} \mathrm{C}$-urea breath test and by the rapid urease test (CLO test) after antral biopsy. ${ }^{56}$ Samples of gastric juice for the measurement of urea and ammonia concentration can be readily obtained during diagnostic upper gastrointestinal endoscopy or by nasogastric intubation. As a result it has also been suggested that the measurement of the gastric juice concentrations of either urea or ammonium alone may also be used to detect this infection. Workers disagree about which of these two gastric juice constituents best detects the presence of $H$ pylori infection. Marshall et al considered that gastric juice urea concentration best detected infection and reported mean concentrations of 0.45 $\mathrm{mmol} / \mathrm{l}$ in subjects with $H$ pylori infection and
$2.9 \mathrm{mmol} / 1$ in those not infected. ${ }^{7}$ Others have found gastric juice urea concentrations of $3.27 \mathrm{mmol} / 1$ and $4.8 \mathrm{mmol} / 1$ in infected subjects and no difference between infected and non-infected subjects. ${ }^{89}$

Marshall et al reported mean ammonium concentrations of $34 \mathrm{mmol} / 1$ and $11 \mathrm{mmol} / 1$ in infected and non-infected subjects, respectively. Kim et al found that gastric juice ammonium concentrations were a good predictor of infection if a threshold of $3 \mathrm{mmol} / \mathrm{l}$ was exceeded, and reported mean concentrations of $5.48 \mathrm{mmol} / 1$ and $1.26 \mathrm{mmol} / \mathrm{l}$, respectively. ${ }^{8}$

The methods used to measure urea and ammonium concentrations in previous reports have not been well described. As a low gastric juice $\mathrm{pH}$ and the presence of ammonium ions could interfere in the measurement of urea and a low $\mathrm{pH}$ could also interfere in the enzymatic measurement of ammonium these different reports may be explained by the use of different methods of analysis. An assessment of methods of measuring urea and ammonium concentrations in gastric juice samples was therefore conducted.

\section{Methods}

Following the passage of a nasogastric tube and pentagastrin stimulation gastric juice was collected from one healthy volunteer who had $H$ pylori infection. The gastric juice sample was stored at $-20^{\circ} \mathrm{C}$ until analysis.

The effects of $\mathrm{pH}$ and gastric juice ammonium concentration on the imprecision, inaccuracy, and detection limit of four methods of urea analysis were investigated. These were a rate reaction enzymatic method automated on the Cobas Bio (Roche, Welwyn Garden City, Herts, England), the o-phtalaldehyde method automated on the Excel analyser (American Monitor, West Sussex, England), a manual diacetylmonoxime method (Sigma Chemical Company, Dorset, England) and a manual urease method linked to the Berthelot reaction (Sigma Chemical Company, Dorset, England). The effect of $\mathrm{pH}$ on the inaccuracy and imprecision of the enzymatic ammonia method automated on the Cobas Bio (Roche, Welwyn Garden City, Herts, England) (Sigma Chemical Company, Dorset, England) was also investigated.

EFFECT OF PH ON THE MEASURED GASTRIC JUICE UREA CONCENTRATION

After measuring the basal $\mathrm{pH}$ of the gastric juice using a Corning $220 \mathrm{pH}$ meter (Corning, Herts, England) $75 \mu \mathrm{l}$ of $2 \mathrm{~mol} / 1$ 
Table 1 Effect of gastric juice pH on measurement of urea concentrations after addition of urea, to give 5 mmoll/ concentration

\begin{tabular}{lcccc}
\hline & \multicolumn{4}{c}{ Mean urea concentration in gastric juice (mmolll) } \\
\cline { 2 - 5 } & $p H 1.56$ & $p H 4.13$ & $p H 6.49$ & $p H 1.60$ \\
\hline $\begin{array}{l}\text { o-Pthalaldehyde method } \\
\text { Diacetylmonoxime method }\end{array}$ & 4.8 & 4.6 & 4.6 & 4.9 \\
$\begin{array}{l}\text { Urease method } \\
\text { unblanked }\end{array}$ & 4.5 & 4.3 & 4.3 & 4.9 \\
$\begin{array}{l}\text { (blanked) } \\
\text { Berthelot linked }\end{array}$ & 7.0 & 6.9 & 6.9 & 6.6 \\
$\quad$ urease method & $(5.2)$ & $(5.1)$ & $(5.2)$ & $(4.8)$ \\
\hline
\end{tabular}

sodium hydroxide was added to a $5 \mathrm{ml}$ portion. This increased the $\mathrm{pH}$ to 4.0 and a portion of this gastric juice was collected. The $\mathrm{pH}$ of the remainder was again increased to $\mathrm{pH} 6.5$ by the addition of more sodium hydroxide solution and a portion was again collected. The $\mathrm{pH}$ of the remaining gastric juice was then titrated back to the original value by the addition of about $50 \mu \mathrm{l}$ of $1 \mathrm{~mol} / 1$ hydrochloric acid to exclude any dilutional effect on the measured urea concentration. Portions $(0.9 \mathrm{ml})$ of the four $\mathrm{pH}$ adjusted gastric juice samples then had $0.1 \mathrm{ml}$ of stock $50 \mathrm{mmol} / \mathrm{l}$ urea solution or deionised ammonia free water added to produce gastric juice samples with a low urea concentration, or $5 \mathrm{mmol} / \mathrm{l}$ urea.

The inaccuracy of the measurement of urea in gastric juice samples with their native unadjusted $\mathrm{pH}$ was assessed by calculating the recovery of urea in portions of gastric juice to which urea had been added to give concentrations of $2 \cdot 5,5,10$ and $20 \mathrm{mmol} / 1$. The samples were assayed by each method in triplicate.

\section{EFFECT OF AMMONIUM CHLORIDE ON MEASURED UREA CONCENTRATION}

Gastric juice samples had $0.1 \mathrm{ml}$ of 100 $\mathrm{mmol} / 1$ solution of ammonium chloride added to increase the total ammonium concentration by $10 \mathrm{mmol} / \mathrm{l}$. These samples containing ammonia were split into two portions and stock urea solution added to give a final urea concentration of $5 \mathrm{mmol} / \mathrm{l}$ in one portion. The concentrations of urea were then measured in each of the portions of gastric juice by all four methods.

\section{EFFECT OF PH ON THE MEASURED GASTRIC} JUICE AMMONIUM CONCENTRATION

Samples of gastric juice had their $\mathrm{pH}$ adjusted as described for urea. Portions of $100 \mathrm{mmol} / 1$ ammonium chloride solution were then added to produce $5 \mathrm{mmol} / 1$ and $10 \mathrm{mmol} / 1$ ammonia concentrations. Samples were then analysed in quintuplicate for ammonium concentration using an enzymatic method

Table 2 Interassay imprecision in measurement of urea in gastric juice samples

\begin{tabular}{|c|c|c|c|c|}
\hline & \multicolumn{4}{|c|}{ Coefficient of variation at a urea concentration of: } \\
\hline & $2.5 \mathrm{mmol} / \mathrm{l}$ & $5 \mathrm{mmol} / \mathrm{l}$ & $10 \mathrm{mmol} / \mathrm{l}$ & $20 \mathrm{mmol} / \mathrm{l}$ \\
\hline $\begin{array}{l}\text { o-Pthalaldehyde method (\%) } \\
\text { Diacetylmonoxine method (\%) } \\
\text { Urease method blanked (\%) } \\
\text { Berthelot linked urease method (\%) }\end{array}$ & $\begin{array}{r}5 \cdot 4 \\
16 \cdot 0 \\
5 \cdot 4 \\
45 \cdot 6\end{array}$ & $\begin{array}{r}6 \cdot 0 \\
12 \cdot 0 \\
2 \cdot 8 \\
20 \cdot 4\end{array}$ & $\begin{array}{r}4 \cdot 6 \\
9 \cdot 8 \\
10 \cdot 2 \\
33 \cdot 5\end{array}$ & $\begin{array}{r}3 \cdot 9 \\
8 \cdot 3 \\
10 \cdot 6 \\
59 \cdot 2\end{array}$ \\
\hline
\end{tabular}

(Sigma, Dorset, England) adapted for the Cobas Bio centrifugal analyser.

The inaccuracy of the ammonia method was assessed by measuring the recovery of ammonium chloride which was added to portions of gastric juice to give final concentrations of $2.5,5,7.5$ and $10 \mathrm{mmol} / \mathrm{l}$. Basal gastric juice samples collected from several other subjects who had $H$ pylori infection were analysed in replicate to assess the imprecision of measurement using native gastric juice.

\section{Results}

EFFECT OF PH ON UREA MEASUREMENT

A change in the $\mathrm{pH}$ of the samples did not noticeably interfere with the measurement of urea by the o-pthalaldehyde, diacetylmonoxime, or the blanked urease methods (table 1). The Berthelot linked urease method resulted in lower concentrations of urea at each $\mathrm{pH}$ tested. The use of $0.2 \mathrm{~mol} / 1$ phosphate buffer as a diluent for the Berthelot method did not increase the urea concentrations obtained by this method. The enzymatic urease method required blanking as the mean basal gastric juice urea concentration was $1.8 \mathrm{mmol} / 1$ with this method compared with $0.2 \mathrm{mmol} / \mathrm{l}$ using the other methods.

The mean (range) percentage recovery of added $5 \mathrm{mmol} / 1$ urea with the blanked enzymatic urease method was $102 \%$ (97-105\%), with the o-pthalaldehyde method 95\% (92-98\%), with the diacetylmonoxime method it was $90 \%(89-98 \%)$, and with the Berthelot reaction it was $72 \%(60-86 \%)$.

The interassay coefficient of variation (CV) of analysis at each of the urea concentrations investigated showed that the blanked urease enzymatic method and o-pthalaldehyde methods were least imprecise (table 2).

\section{EFFECT OF AMMONIUM ON THE MEASUREMENT} OF UREA

The addition of $10 \mathrm{mmol} / \mathrm{l}$ ammonium chloride to the gastric juice did not interfere with the measurement of urea by either the diacetylmonoxime method or the o-pthalaldehyde method. The addition of ammonium chloride resulted in the detection of a urea concentration of $4.2 \mathrm{mmol} / \mathrm{l}$ by the enzymatic urease method compared with a mean of 0.96 $\mathrm{mmol} / \mathrm{l}$ by the other methods. When a blank sample was also analysed then interference by ammonium was controlled.

\section{EFFECT OF PH ON THE MEASUREMENT OF GASTRIC JUICE AMMONIUM}

A change in gastric juice $\mathrm{pH}$ over the range 2.29 to $7 \cdot 20$ did not affect the measurement of ammonium (table 3 ). The samples were diluted 1 in 4 or 1 in 20 (before analysis) depending on the ammonium concentration

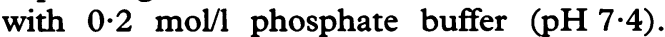
This reduced the concentration of ammonia in the sample to that of the linear range of the assay which was between $30 \mu \mathrm{mol} / 1$ and 1 $\mathrm{mmol} / \mathrm{l}$. The phosphate buffer neutralised the effects of gastric juice acidity. If distilled 
Table 3 Absence of any effect of $\mathrm{pH}$ of gastric juice samples on measurement of ammonium concentration ( $n=5)$ using enzymatic method adopted for Cobas Bio

\begin{tabular}{|c|c|c|c|c|}
\hline & \multicolumn{4}{|c|}{$\begin{array}{l}\text { Gastric juice ammonium concentration (SD) at a range of } \\
\text { sample pH: }\end{array}$} \\
\hline & pH $2 \cdot 29$ & pH 4.04 & $p H 7 \cdot 20$ & $p H 2 \cdot 29$ \\
\hline \multicolumn{5}{|l|}{ Ammonium chloride } \\
\hline not added & $\begin{array}{l}0.98 \\
(0.010)\end{array}$ & $\begin{array}{l}0.97 \\
(0.016)\end{array}$ & $\begin{array}{l}0.93 \\
(0.016)\end{array}$ & $\begin{array}{l}0.90 \\
(0.016)\end{array}$ \\
\hline $\begin{array}{l}5 \mathrm{mmol} / \mathrm{l} \text { added } \\
\text { ammonium chloride }\end{array}$ & $\begin{array}{l}5.5 \\
(0.14)\end{array}$ & $\begin{array}{l}5 \cdot 0 \\
(0.05)\end{array}$ & $\begin{array}{l}5 \cdot 4 \\
(0.07)\end{array}$ & $\begin{array}{l}5 \cdot 2 \\
(0 \cdot 26)\end{array}$ \\
\hline $10 \mathrm{mmol} / 1$ added & $9 \cdot 8$ & $9 \cdot 8$ & $9 \cdot 8$ & $9 \cdot 4$ \\
\hline ammonium chloride & $(0 \cdot 16)$ & $(0.07)$ & $(0.51)$ & $(0 \cdot 26)$ \\
\hline
\end{tabular}

water was used as the diluent then there was an apparent reduction in measured concentrations of ammonia.

The intra-assay coefficient of variation of the standard with $10 \mathrm{mmol} / 1$ ammonium concentration was $1.0 \%$ while the interassay coefficient of variation was $2 \cdot 0 \%$. Using samples from patients the intra-assay coefficient of variation including dilution varied from $8.5 \%$ at an ammonium concentration of 2.3 $\mathrm{mmol} / 1$ to $1 \%$ at an ammonium concentration of $13.0 \mathrm{mmol} / 1$.

The interassay coefficient of variation of the enzymatic ammonia method (including dilution) using the gastric juice samples with added ammonium chloride ranged from $17 \cdot 2 \%$ at an ammonium concentration of $2.5 \mathrm{mmol} / 1$ to $6.5 \%$ at an ammonium concentration of $7.5 \mathrm{mmol} / \mathrm{l}$. The interassay coefficient of variation from a range of samples from several subjects ranged from $8.5 \%$ at $2.3 \mathrm{mmol} / 1$ to $1.5 \%$ at an ammonium concentration of $11.1 \mathrm{mmol} / 1$.

The measured ammonium concentration in the samples was linear with serial dilution. The detection limit of the assay was $30 \mu \mathrm{mol} / 1$.

\section{Discussion}

This study has shown that the differing reports of urea concentration in gastric juice samples $^{7-9}$ cannot be explained by the effect of gastric juice $\mathrm{pH}$ on different methods of urea analysis. It has also shown that the enzymatic urease method, when used without blanking, resulted in an apparent increase in urea concentration due to the presence of high concentrations of ammonium which may occur with infection by $H$ pylori. In the two studies which found no difference in the urea concentration in gastric juice before and after eradication of $H$ pylori urease methods were used. ${ }^{89}$ If these methods had not been blanked then this might explain the results.

Raised plasma urea concentrations result in an increased concentration of urea in gastric juice. We have already shown that the production of ammonia by $H$ pylori urease activity may be stimulated by the infusion of urea. ${ }^{10}$ Raised plasma urea concentration in subjects with chronic renal failure therefore results in raised gastric juice urea concentrations and raised gastric juice ammonium oncentrations. ${ }^{8}$ The reports of high concentrations of gastric juice urea in subjects with $H$ pylori infection could therefore also be explained by raised plasma urea concentrations.
The o-pthalaldehyde method and the enzymatic urease method, when blanked, proved the most suitable methods for the measurement of urea. The Berthelot method of measurement of urea did not prove suitable for use with gastric juice samples. Its imprecision and inaccuracy, when compared with the other manual method, suggested an interference in the method. This was not due to the $\mathrm{pH}$ of the sample because buffering the sample $\mathrm{pH}$ by reconstituting the urease enzyme with $0.2 \mathrm{~mol} / 1$ phosphate buffer $(\mathrm{pH} 7.4)$ instead of the deionised water did not eliminate the interference. It may have been due to a matrix effect of the gastric juice, such as the concentration of bile acids. Although this method could account for apparent differences in gastric juice urea or ammonium concentrations, it was not used in any of the three studies reported..$^{7-9}$

This study has also shown that the differing reports of gastric juice ammonium concentration might be explained by the effect of gastric juice $\mathrm{pH}$. The $\mathrm{pH}$ of the sample did not interfere in the measurement of ammonium concentration when the samples were diluted with $0.2 \mathrm{~mol} / 1$ phosphate buffer $(\mathrm{pH}$ $7 \cdot 4)$ before analysis to bring the ammonia concentration to within the linear range of the method. If the gastric juice acidity had not been neutralised by the diluent buffer then this caused an apparent reduction in gastric juice ammonium concentrations. This might account for reports of low gastric juice ammonium concentrations in the presence of $H$ pylori infection.

The differences in reports of gastric juice urea and ammonium concentrations might also have been due to a failure to distinguish properly between those subjects with $H$ pylori infection and those without.

In conclusion, the enzymatic urease method for the measurement of urea and the o-pthalaldehyde method proved the most suitable for the measurement of urea in gastric juice samples.

1 Marshall BJ, McGechie DB, Rogers PA, Glancy RG. Pyloric campylobacter infection and gastroduodenal disease. Med F Aust 1985;142:439-44.

2 Marshall BJ, Goodwin CS, Warren JR, Murray R, et al. Prospective double blind trial of duodenal ulcer relapse after eradication of Campylobacter pylori. Lancet after eradication

3 Megraud F, Barnet F, Garner $M$, Lamouliatte $H$. Characterisation of Campylobacter pyloridis by culture, enzymatic profile and protein content. F Clin Microbio 1985;22:1007-10.

4 Ferrero RL, Hazel SL, Lee A. The urease enzymes of Campylobacter pylori and a related bacterium. $f \mathrm{Med}$ Microbiol 1988;27:33-40.

5 Marshall BJ, Warren JR, Francis GJ, Langton SR, Goodwin CS, Blincow ED. Rapid urease test in the management of associated gastritis. Am $\mathcal{F}$ Gastroenterol 1987;82:200-10.

6 Marshall BJ, Surveyor I. Carbon 14 urea breath test for the diagnosis of Campylobacter pylori associated gastritis. $\mathcal{F}$ Nucl Med 1988;29:11-16.

7 Marshall BJ, Langton SR. Urea hydrolysis in patients with Campylobacter pyloridis infection. Lancet 1986;i:965-6. Campylobacter pyloridis infection. Lancet 1986;1:965-6.
$8 \mathrm{Kim} \mathrm{H}$, Park C, Jang WI, et al. The gastric juice urea and Kim H, Park C, Jang WI, et al. The gastric juice urea and Am f Clin Pathol 1990;94:187-91.

9 Bornschein W, Baurefeind A, Heimann KL. UreaseSchnelltests bei Campylobacter pylori besledlung der Magenschleimhaut [A rapid urease test in Campylobacter pylori colonisation of the gastric mucosa]. Gastroenterol $₹$ 1989;49:54-8.

10 Chittajallu RS, Neithercut WD, MacDonald AMI, McColl KEL. The effect of increasing Helicobacter pylori ammonium production by urea infusion on plasma gastrin concentrations. Gut 1991;32:21-4. 